\title{
Social Investment of Pension Funds Perspective: The Case of Russia
}

\author{
Alena Smelova \\ Associate Professor at Economic Sociology Chair, St. Petersburg State University \\ a.a.smelova@spbu.ru
}

\section{Doi:10.5901/mjss.2015.v6n6p170}

\begin{abstract}
The current survey aims to draw a perspective on the social investment of pension funds in Russia. The author defines the concept within the context of the Conventions Theory. The practice of the social investment of pension funds presupposes a complex architecture of social order that combines dominant domestic market world principles with elements from the civic and industrial world. The new order is achieved through a compromise of domestic value orientations and the competition for pension funds, the collective character of investments with its temporal and spatial attachment, calculation of risks and profits, as well as focus on results. The study employs a qualitative research with a regression analysis. The results indicate that in St. Petersburg (Russia), despite the individuals' pessimism towards the pension system, there is a glimmer of interest in this issue. Respondents admit the likelihood of socially responsible investing their pension funds in case the rate of return on these investment projects will not be less than the interest on bank deposits. The important factors of attracting pension funds in social projects are: the local character of investment projects, the short-term individual consumption perspective, and the state regulation of social investment market. The author concludes that social investing has a potential to become an alternative way in the pension system evolution in Russia.
\end{abstract}

Keywords: Socially responsible investment, social investment of pension funds, pension reform, the Conventions Theory, welfare states.

\section{Introduction}

The starting point in the debate on the reform of the pension system was a World Bank report «Averting the old age crisis» in 1994. Welfare states faced with the problem of choosing the appropriate approaches to reforming the pension system. States have begun to reconsider the basic principles of the pension sector and rebuild its institutions. Russia is no exception; it adopted new pension legislation, created pension services market, and introduced new principles of pension rights and the calculation of pensions. In Russia, the pension reform began more than 20 years ago. Since then, its mechanism has been radically changed, in fact, four times. And now, it is time to reflect on its first results to assess whether the direction of reform has been chosen correctly and finally, to think about its future.

\section{Literature Review}

The reform of social security received a serious theoretical development in social sciences. A comparative perspective on social security reform across Europe has been introduced by Feldstein and Siebert (2002). While the issue of the distributional aspects of various instruments for social security reform in the US has been proposed for discussion by Feldstein and Liebman (2002). Significant scientific contribution to the solution of the problem of the transition from the PAY-AS-YOU-GO (PAYG) pension system to a mixed funded arrangement has been made by Modiliani and Muralidhar (2004). The complex relations of social security system and financial markets have been described by Munnel and Sass (2006), and Krueger and Kubler (2006). The question of being a socially responsible investment has been also widely discussed by Hayden (1989), Cumming, and Johan (2007), Starr (2008). A practical guidance for pension funds moving towards a sustainable investment has been presented by Woods and Urwin (2010).

Furthermore, Vitols (2011) surveys the socially responsible initiatives and policies among the European pension funds. Also, Sievänen, Rita, and Scholtens (2013) explore the drivers of responsible investment for pension funds. Meanwhile, Sandberg (2013) focuses on the justifying fiduciary duty of socially responsible investments for pension funds. Additionally, Marti-Ballester (2015) looks at people reactions to investment into ethical pension plans.

Although the issue of pension funds investment in social projects is relatively new in Russia, it has been well studied. Ermakov (2007) investigates the investment activities of non-state pension funds in the implementation of 
regional social projects. Grigoriev (2010) has his glance on the question of corporate social responsibility in the pension system. Besides, Kalmykov (2015) provides an economic analysis of investment mechanism of pension insurance. While Pochinok, Andryushchenko, Savina, Spirina, \& Maloletko (2015) examine the funded part of private pension funds in the structure of investments in the Russian financial market.

\section{Research Problem}

The dynamics of pension reform in Russia brings new challenges to public discussion. Today, one of the most discussed topics is the issue of the abolition of the mandatory funded pension. According to the Public Opinion Foundation* (Presnyakova, 2014), most of the respondents (64\%) are unable to express their attitude to the problem, on one hand, due to the lack of information on the results of public debates; and on the other hand, due to the general distrust to the state and the fear that people will lose their pensions. To add, others do not understand the mechanism of the funded system.

In general, people are not ready to form a contributory pension independently (43\%), with the exception of educated and wealthy people living in big cities (St. Petersburg and Moscow). They are willing to take financial responsibility for their own future (4\%) due to a distrust to the state pension system. More than $32 \%$ are planning to form funded pension in the future.

The main strategy in the retirement age is to continue working while receiving a pension. Nearly three-quarters of the respondents (70\%) see the state pension as the primary financial source of their retirement and $36 \%$ of respondents are planning to continue working after retirement. Also, more than $17 \%$ rely on their relatives and children and $31 \%$ have personal savings (Presnyakova, 2014).

So, here come new questions for theoretical verification and comprehension. Why do individuals ignore the issue of the transition from the distributive pension system to a funded system and its financial institutions? What are the reasons that explain their behavior? Should pension investment be focused solely on profit objectives to attract their attention or to encompass social objectives? Do individuals distrust the pension system because its higher common principle does not fit their notion of justice? Finally, could social investment of pension funds become an economically effective and socially acceptable practice in Russia that will provide a pension system with an alternative way of institutional change?

\section{Theoretical Framework}

In order to explain the problem, let us refer to the Convention Theory (Boltanski, Thévenot, 2006). Modern funded pension system operates in the logic of the market and domestic worlds, which are in conflict.

The model of the domestic world is based on the principles of stability, low volatility, persistence, and orientation to the past. The higher common principle is to maintain traditions, thus, preserving solidarity ties in society. In contrast, the model of the market world is built on the principles of competition for rare goods, and focused on short-term interests, i.e., ignoring time and space perspectives. This competition between people is resolved by the price mechanism. Therefore, the higher common principle of the market world is competition.

The Razdatok (distributive) market economy paradigm is an example of a compromise involving the domestic and market worlds. In the framework of this paradigm, the institutional structure of Russian economy embodies two types of economies: the razdatok and market economies (Bessonova, 2013). The main type of economic institutions in Russian economic evolution is razdatok. The market institutions are supporting, which means they appear in transition periods when the economy faces difficulties and is in search of alternative ways to solve the problems. In its economic development, Russia has passed three periods of razdatok and is on the verge of the fourth. Each period contains the elements reached in the previous transition period, but on a new stage of economic evolution. Therefore, the introduction of the accumulative principle in pension reform should be kept (as a transition period element), but organically integrated in a new one - liberal type of razdatok with multifaceted social contracts. Otherwise, the individuals will lose confidence in the pension system.

Institutes of these distribution economies are complementary and therefore, sustainable. Moreover, they are the basis for the construction of the pension system on the principles of solidarity and competition for investment resources.

In tsarist times, the right to a pension could be given only by service, primarily the military service, to the Russian

"The survey was conducted among the residents of 100 urban and rural settlements in 43 regions of Russia, with 860 respondents born in 1967 and younger, and the statistical error does not exceed 3.6\%. August 21-24, 2014. 
throne. Subsequently, the pension system has been steadily expanded to include the broad categories of people who are now called «civil servants». In Soviet times, pension became available to the general public, while at the same time, there was a personal pension for privileged groups (military, academics, heroes of the Soviet Union and Socialist Labor, and others) (Krechetnikov, 2010).

Today, a guaranteed average pension is the privilege of workers with public permanent jobs and indefinite employment contracts. Others are forced to adapt to the realities of precarious employment and income volatility. Besides, getting a high income in certain periods of one's working life does not guarantee the conservation and conversion of this income (when investing a funded portion of pension funds in financial products) to a decent pension in the future. There is a time lag between the creation of material wealth in the present in the form of conservation funds and its consumption in the future, which cannot be overcome due to the depreciation of money (for example, the rate of inflation in Russia in May 2000 and May 2015 amounted to 414.01\%) (The inflation rate in Russia, 2015). In this regard, it seems to be a good alternative to invest pension funds in current social projects aimed at Russian economic development.

To date, the main criterion for placing pension savings is the maximum return on assets with adequate risk. Thus, the requirements to achieve economic efficiency and high performance investment are met. However, there is another criterion - social. The basis for the selection criterion is the goals of the society, which in turn, sets the values and norms. The more complex the socio-economic system is, the greater the number of elements within each component, and its combinations should be included in the program of investment policy in a time perspective (Hayden, 1989).

Retirement savings are a large amount of unallocated funds, which can be used either for the implementation of speculative transactions, or be invested into social projects to address specific problems. The return on social investment is lower than on financial investment, but the risks are expected to be also lower due to the comprehensive insurance model of social investment, as well as the requirements for a public offering of social reports by organizations before contracting. Moreover, it is assumed that the funding gets the projects that demonstrate achievement of specific social outcomes («pay-for-success») (Impact investing, 2014). For comparison, in 2014, the return on pension investment (in currency and securities) in the segment of non-state pension services ranged from - 5.23\% to $11.22 \%{ }^{*}$ (The Central Bank of Russia, 2015). However, the pension funds are designed to save money rather than to multiply it.

\section{Research Method and Data Collection}

The survey was conducted in February/March 2015 among formally employed respondents living in St. Petersburg between the ages 18 and 60 years. The volume of the sample is 764 people, and the sampling error is no greater than $5 \%$. The sample does not include people with low and high income. This is done deliberately because the financial behavior of these people differs from the average taxpayers. Besides, the research was carried out in the most liberal and European-oriented city in Russia that also sets sample limitations to the survey. The analysis is based on more than 62600 valid responses. The main method of data collection was a structured interview. The interviews were carried out face-to-face at the residence of the respondents. The interview guide contained 82 questions grouped under the following headings: (1) demographic characteristics and lifestyle, (2) the level of income and wealth, (3) personal values and beliefs, (4) the values and beliefs about Russia, (5) financial strategies and expectations, and (6) the values and beliefs that define the investment strategy of pension funds (De Bondt, 2004). The data was analyzed with regression.

Sample descriptions. Distribution by gender: male - 51\%, female - 49\%. Distribution by age: 18 - 35 years - 44\%, 36 - 60 years - $56 \%$. Distribution by status: married - $51 \%$, single - $27 \%$, divorced - $9 \%$, and widowed - $4 \%$. Distribution by dependents: $44 \%$ have children below 21 years of age and $24 \%$ have elderly parents who are financially dependent. I sampled middle and upper middle class respondents. For the majority (79\%), the average monthly income is between 20 000 and 90000 (the average salary in St. Petersburg is 40550 rubles) (Petrostat, 2015). 9\% are employed in a large public organizations, $15 \%$ in large international companies, $16 \%$ in small public organizations, $11 \%$ in small international companies, $45 \%$ are involved in small private businesses and self-employment, and $2 \%$ are engaged in the household. A large majority (60\%) prefer to save where nearly $1 / 5$ has savings in the currency, 1/10 in the form of real estate, and only $6 \%$ save in financial instruments.

$3 / 4$ of the respondents have higher education. $86 \%$ speak foreign languages: $42 \%$ speak at least one foreign language and $35 \%$ speak two. Annually, $94 \%$ buy (and read) books where $42 \%$ buy 5 or more books a year (mostly fiction, historical, psychological and financial books).

Respondents regularly search for new information. The main source of information is the Internet - 93\%, TV - 47\%,

\footnotetext{
* The only exception is the private pension fund «Bashkomsnabbank» with an extra-ordinary $42.24 \%$ return on pension investment.
} 
and radio - 22\%; $73 \%$ use the computer on a proficient level. Most travel a lot (98\%) with the following breakdown: alongside Russia - 71\%, Europe - 62\%, CIS - 31\%, Southeast Asia - 15\%, and Africa - 15\%. As for religious affiliation, $75 \%$ are Orthodox, $4 \%$ are Protestants, $2 \%$ are Christians (others), 5\% are Buddhists, $2 \%$ are Jews, $2 \%$ are Muslims (Sunni), and $9 \%$ are Atheists. Despite differences in religious beliefs, $89 \%$ of the respondents feel compassion for the needy.

\section{Results}

\subsection{Personal values and beliefs about Russia}

As I study a correlation between cultures (mental frames) and the decisions made about the investment of pension funds, it is important to examine what are respondents' values and beliefs (De Bondt, 2004).

Out of 25 possible answers, the top 5 values are family, health, love, self-realization, and personal happiness / communication with friends. Important values are also considered to be diversity, social change, time, and quality of life. Meanwhile, the majority of the respondents appeared to ignore the following: equality, justice, and responsibility.

It is believed by $89 \%$ of the respondents that Russian society needs change, $38 \%$ of which are people under 35 years. Russia is not considered to be a country where social justice is guaranteed (82\%). There is a significant skepticism about the government programs because they tend to be ineffective, and many say that the distribution of the budget into social projects is falling (85\%). The standard of living of today's retirees is worse than in the Soviet Union (67\%). They believe that sanctions against Russia have a negative impact on the income of citizens (75\%). Labor migration is believed not to be an indicator of social stability in the country by $75 \%$ of respondents. Most (53\%) think that the values of the market economy contribute to the emergence of well-being in the community. Globalization and international companies are believed to have a negative effect on the Russian economy (60\%). Respondents (78\%) mostly agree that the developed financial system is the key to economic development and the prosperity of its citizens.

\subsection{Values and Beliefs about Financial Strategy}

Among the respondents, $47 \%$ consider themselves financially literate (20\% are in the age group $25-35)$. The majority assess their level of financial literacy at a satisfactory level. Respondents regularly use financial services: depository $47 \%$, credit - $18 \%$, brokerage - $11 \%$, financial and investment consulting - $13 \%$, trust funds - $2 \%$, and did not use any services $-20 \%$. Furthermore, $62 \%$ of the respondents have dealt with financial fraud.

The most popular financial products are: the payment of utility services, telecommunication, and the Internet - 78\%; travel insurance - 55\%; credit card - 45\%; life and health insurance - 40\% (mostly respondents under 35); and consumer credit and debit card $-38 \%$.

The main economic indicators listed in media, which are in the sample respondent focus (multiple choice question): exchange rate - $33 \%$, oil price $-21 \%$, inflation - $17 \%$, unemployment - $10 \%$, industrial production - $6 \%$, the trade balance $5 \%$, RTS, MICEX - 4\%, business activity index - $2 \%$, and economic growth rate - $1 \%$.

The level of trust in financial institutions in the Russian society is relatively low: Russian banks $-36 \%$, international banks - 44\%; and confident with national currency - 27\%. Nearly half (47\%) trust the dollar and the rest (42\%) in euro. The level of confidence with the Pension Fund of the Russian Federation (56\%) is three times higher than with private pension funds (19\%); while it is low with investment companies (15\%) and twice as much with the insurance companies (34\%).

\subsection{Values and Beliefs about Pension Funds Investment}

The vast majority of the respondents allocated their pension funds in the Pension Fund of the Russian Federation and only $18 \%$ transferred their pension funds to non-state pension funds. The main criteria for choosing the non-state pension fund are its reputation in the market of pension services (41\%) and high yield (25\%). Areas of investment play no special role.

The following are opinions about the investment of pension funds in social projects: to solve the social problems at their expense - $61 \%$, an act of charity - $34 \%$, a way to multiply funds - $5 \%$, while the answer «the way to save money» is statistically indistinguishable.

In case of getting profits of no less than on bank deposits, nearly $1 / 4$ of the respondents have agreed to invest their 
pension savings in social projects. The main areas of social investment are in table 1. (Multiple choice)*:

Table 1. The issues for social investment of pension funds.

\begin{tabular}{|l|c|}
\hline The issues for social investment of pension funds & \\
\hline Health care centers & $0.66)$ \\
\hline Waste management & $(0.61)$ \\
\hline Children's educational and family leisure centers & $(0.57)$ \\
\hline Social rehabilitation centers & $(0.43)$ \\
\hline Food quality control & $0.41)$ \\
\hline Small and medium-sized businesses, providing employment for socially vulnerable groups of the population & $(0.33)$ \\
\hline Professional education programs & $(0.29)$ \\
\hline Human rights & $(0.21)$ \\
\hline Infrastructure projects & $0.18)$ \\
\hline Employment of graduates of children's homes & $(0.16)$ \\
\hline Employment of ex-prisoners & $(0.16)$ \\
\hline The organization for conflict resolution projects & $(0.16)$ \\
\hline Sport centers & $0.14)$ \\
\hline Social geriatric centers & $0.11)$ \\
\hline The revival of traditional crafts and industries & 0 \\
\hline The implementation of housing reform projects & 0 \\
\hline
\end{tabular}

Resource: Primary data received by the author.

\section{Discussion}

In general, the educated and financially secured individuals working in St. Petersburg are pessimistic about the pension reform evolution in the country. Distrust of pension institutions in Russian society is one of the most important issues, which is multi-dimensional. It stems from the distrust of the major functional systems of society - the political system, the legal system, and the economic system. The destruction of trust in at least one system leads to the destruction in another (Rose-Ackerman, 2001).

Today, the predominant attitude of the respondents to a mandatory funded system is that it seems to be another type of taxation. So, the main strategy for retirement is to wait for a state pension and continue working.

Less than $1 / 2$ of the respondents consider themselves financially literate. Most rate their level of financial literacy as satisfactory, but not enough to make financial manipulations with their pension funds. More than $1 / 2$ of respondents do not trust financial institutions as they have encountered financial fraud on personal experience. The most popular tool for savings is bank deposits that allow to save money within the official inflation rate. Unlike other financial products (for example, loans and insurance), the logic of bank deposits is clear to the majority of respondents so it acts as an economic guide of their financial behavior. Currency exchange rates and oil prices are the main indicators of economic changes for them.

In St. Petersburg, there is a glimpse of interest in the social investing of pension funds. Almost $1 / 4$ of the respondents admit the likelihood of investing their pension funds in case the rate of return on investment projects will not be less than the interest on bank deposits. In May 2015, the average interest rate on deposits is $12.98 \%$ in Rubles, $4.23 \%$ in US dollar, and $3.7 \%$ in Euros. The areas of social investment of future pensioners reflect their values. In general, the values correspond to the domestic world (family, health, love (personal happiness)).

However, in a large (usually nonnative) city, patriarchal values are refracted in the light of individualism. The problem of responsible investment in a welfare society is challenged by personal gains. Therefore, investing pension funds in infrastructure projects are not popular, according to the received answers, despite the calculated profitability (Kalmykov, 2015). The respondents are not willing to sacrifice any part of their income if it will not contribute to their personal well-being. The majority of the respondents feel compassion for those in need, but they are not willing to invest in social projects in order to prevent acute social problems.

In fact, the social investment of pension funds presupposes a complex architecture of social order that combines

\footnotetext{
* The list has been compiled on the basis of the most popular areas of social projects supported by the «New Eurasia» and «Our future» Foundations.
} 
dominant domestic market world principles with elements of the civic and industrial worlds (Boltanski, Thévenot, 2006). The new order is achieved through a compromise of domestic value orientations and the competition for pension investments, its temporal and spatial attachment, as well as focus on results. The logic of civic world implies the accomplishment of the common good through the mechanism of the collective investment of individual pension funds, following the certain rules, norms, and values of the project participants. The logic of the industrial world is implemented through the effective management of these projects. This, in turn, involves the use of accounting and measurement tools to anticipate the development of the economic situation and therefore, the calculation of risks and profits over time. Efficiency, combined with the dynamism and orientations for the future, allows the development of new directions in social investment.

Thus, the important factors of attracting pension funds in social projects are: the local character of investment projects, the short-term individual consumption perspective, and the state regulation of social investment market. The external force capable to keep the new order legitimate is the state financial institutions, in particular, the Pension Fund of the Russian Federation (the level of confidence is three times more than the confidence in private pension funds). This is due to traditional views about the place of storage and the state machinery of pension funds management; in other words, due to the dominance of domestic world logic.

\section{Conclusion}

So the question is: how stable is the data describing the social values and the financial behavior of future retirees? Will they change over time? Of course they will differ while the employment situation of today's respondents, the hierarchy of their values, and the direction of the social investment will change.

However, one thing is clear - finance is a powerful tool for solving problems in society and for increasing general welfare (Schiller, 2012). Through responsible investing of pension funds, it is possible to construct a socio-economic environment of welfare states, in accordance with the available resources and the needs of society. To conclude, this practice has a potential to become an alternative way in pension system evolution.

\section{References}

Bessonova, O.E. (2013). The market-(razdatok) distributing paradigm. Personality and culture, 1, 50-54. (in Russian) Boltanski, L., \& Thévenot, L., (2006 [1991]). On justification. The economies of worth. Princeton: Princeton University Press.

Cumming, D., \& Johan, S. (2007). Socially responsible institutional investment in private equity. Journal of Business Ethics, 75(4), 395416.

De Bondt, W. (2004). The values and beliefs of European investors. In K. Knorr Cetina, \& A. Preda (Eds.), The sociology of financial markets (pp. 163-186). Oxford: Oxford University Press.

Ermakov, D.N. (2007). Investing activities of non-state pension funds in regional social projects. Unpublished PhD thesis, Institute of Regional Economic Research. Retrieved from http://www.dissercat.com/content/investitsionnaya-deyatelnost-negosudar stvennykh-pensionnykh-fondov-v-realizatsii-regionalnyk (in Russian)

Feldstein, M., \& Liebman, J.B. (Eds.). (2002). The distributional aspects of social security and social security reform. Chicago, London: University of Chicago Press.

Feldstein, M., \& Siebert, H. (Eds.). (2002). Social security pension reform in Europe/ Chicago, IL, USA: University of Chicago Press.

Grigoriev, A.A. (2010). Corporate social responsibility in the pension system. Unpublished PhD thesis, Institute of Labor and Human Services Insurance. Retrieved from http://www.dissercat.com/content/korporativnaya-sotsialnaya-otvetstvennost-v-sistemepensionnogo-obespecheniya (in Russian)

Hayden, F. G. (1989). Public pension power for socioeconomic investments. Journal of Economic Issues, 23(4), 1027-1045.

Impact investment: The invisible heart of markets. Report of the social impact investment taskforce. 15 September 2014. Retrieved from http://www.socialimpactinvestment.org/reports/Impact\%20Investment\%20Report\%20FINAL[3].pdf

Kalmykov, V.Y. (2015). Investment mechanism of pension insurance and their role in the development of national economy. Mediterranean Journal of Social Sciences, 6.1 S3, 50-54.

Krechetnikov, A. (Analyst) (2010, September 8). Pensions: From royal favor to the natural law [Article]. Russian BBC. Retrieved from http://www.bbc.com/russian/russia/2010/09/100831_pensions_history (in Russian).

Krueger, D., \& Kubler F. (2006). Pareto-improving social security reform when financial markets are incomplete? The American Economic Review, 96, 737-755.

Marti-Ballester, C.P. (2015). Investor reactions to socially responsible investment. Management Decision, 53(3), 571-604.

Modilidiani, F., \& Muralidhar, A. (2004). Rethinking Pension Reform. UK: Cambridge University Press.

Munnell, A.H., Sass, A. (2006). Social security and the stock market: How the pursuit of market magic shapes the system. Kalamazoo, MI, USA: W. E. Upjohn Institute for Employment Research.

Ordin O.V. (2002). Modelling the processes of transition to a funded pension system. Unpublished PhD thesis, Russian Academy of 
Sciences, The Central Economics and Mathematics Institute. Retrieved from http://www.dissercat.com/content/modelirovanieprotsessov-perekhoda-k-nakopitelnoi-pensionnoi-sisteme (in Russian)

Petrostat. The territorial body of the Federal State Statistics Service of St. Petersburg and Leningrad region. Average monthly nominal wage. Retrieved from http://petrostat.gks.ru/wps/wcm/connect/rosstat_ts/petrostat/resources/01f466004d2be67fae9bbff30c79b fa3/02zp_g.pdf

Pochinok, N.B., Andryushchenko, G.I., Savina, M.V., Spirina, A.N., \& Maloletko, A.N. (2015). Place of private pension funds in the financial market. Asian Social Science, 11(14), 161-168.

Presnyakova, Ludmila, (2014), Debate on mandatory funded pension. Public Opinion Foundation. Retrieved from http://fom.ru/special/ pensija.html

Rose-Ackerman, S. (2001). Trust and honesty in post-socialist societies. Kyklos, 54, 415-444.

Sandberg, J. (2013) (Re-)interpreting fiduciary duty to justify socially responsible investment for pension funds? Corporate Governance (Oxford), 21(5), 436-446.

Shiller, R. J. (2012). Finance and the Good Society. Princeton: Princeton University Press.

Sievänen, R., Rita, H. \& Scholtens, B. (2013) The drivers of responsible investment: The case of European pension funds. Journal of Business Ethics, 117(1), 137-151.

Starr, M. A. (2008). Socially responsible investment and pro-social change. Journal of Economic Issues, 42(1), 51-73.

The Central Bank of Russia. Retrieved from http://www.cbr.ru/finmarkets/files/supervision/reports/OPD_NPF_12_2014.xls

The inflation rate in Russia. Retrieved from http://yровень-инфляции.рф/инфрляционные_калькуляторы.aspx

Vitols, S. (2011). European pension funds and socially responsible investment. Transfer, 17(1), 29-41.

Woods, C., \& Urwin, R. (2010). Sustainable investing into practice: A governance framework for pension funds. Journal of Business Ethics, 92, 1-19. 